DOI: 10.17707/AgricultForest.63.1.35

Gordan S. KARAMAN ${ }^{1}$

\title{
NEW SUBTERRANEAN SPECIES OF THE FAMILY NIPHARGIDAE FROM GREECE, NIPHARGUS DENARIUS, SP. N. (CONTRIBUTION TO THE KNOWLEDGE OF THE AMPHIPODA 295)
}

\begin{abstract}
One new species of the family Niphargidae (Crustacea: Amphipoda: Gammaridea), Niphargus denarius, sp. $\mathrm{n}$. is described and figured from the subterranean water of Efimia, Cephalonia, Greece, and its relation to some other members of the genus Niphargus Schiödte, 1949 from Greece and some adjacent regions is discussed. This species belongs to the Supraniphargus group of taxa.

Keywords: taxonomy, Amphipoda, Niphargus denarius, Greece, new taxa, subterranean waters
\end{abstract}

\section{INTRODUCTION}

Based on its specific geographical, geological and climatic position in Europe, the subterranean fauna of Amphipoda in Greece is very rich and highly endemic, although only partially investigated. Within the family Niphargidae, three genera are known from Greece: Niphargus Schiödte, 1849, Exniphargus GK 2016b and Niphargobatoides G. Karaman 2016b; these genera are established based on morphological, ecological and zoogeographical data.

The subterranean genus Niphargus Schiödte, 1849 (Amphipoda: Gammaridea: Niphargidae) from Greece has been investigated by various scientists (S. Karaman, G. Karaman, A. Ntakis, C. Anastasiadou, V. Zakšek, C. Fišer, etc.), and nearly 15 species of this genus are known from this region; the most of them are endemic. Recently we have described a new taxa from Greece, Niphargus spasenijae G. Karaman 2015 from Tasos Island as well as $N$. impexus G. Karaman, 2016a and N. lakusici G. Karaman 2017 from Crete Island.

During our recent studies of Amphipoda from Balkan peninsula, we discovered one new species from Cephalonia, described here based on material given us for study by Dr Giuseppe Pesce from Aquilla, Italy. This species, with elevated number of spines on dactylus of pereopods, belongs to the Supraniphargus group of taxa.

Stanko Karaman (1960) established subgenus Supraniphargus [typus subgeneris: Niphargus illidzensis Schäferna, 1922] for the species with elevated number of spines of dactylus of pereopods. This division was very reasonable because in that period relatively small number of Niphargus species was known.

\footnotetext{
${ }^{1}$ Gordan S. Karaman (corresponding author: karaman@t-com.me) Montenegrin Academy of Sciences and Arts, Podgorica, Montenegro

Note: The authors declare that they have no conflicts of interest. Authorship Form signed online.
} 
During last 50 years numerous new taxa of genus Niphargus have been discovered with various characters, showing that many taxa with this character probably have different origin. This fact doesn't exclude the possibility that Niphargus illidzensis Schäferna 1922 [locus typicus: Ilidža near Sarajevo, Bosnia and Herzegovina] with limited numerous similar taxa represent probably one entity based also on genetically and other characters, although for final decision is necessary to provide further genetic, molecular and taxonomical investigations. For the moment, we use the term Supraniphargus for an artificial group of taxa with elevated number of spines on dactylus of pereopods..

\title{
MATERIAL AND METHODS
}

The studied material was preserved in the $70 \%$ ethanol. The specimens were dissected using a WILD M20 microscope and drawn using camera lucida attachment. All appendages were temporarily submersed in the mixture of glycerin and water (40:60) for study and drawing. The body-length of examined specimens was measured from tip of head to end of telson using camera lucida. All illustrations were inked manually. After the end of the study, the dissected body-parts were submerged in Liquid of Faure on slides and covered by thin cover glass. Some morphological terminology and seta formulae follows Karaman`s terminology (Karaman, G. 1969; 1970; 2012).

The advantage of use of Liquid of Faure is the possibility to remove dissected body-parts from Liquid of Faure by water, and study it again in the various positions under the microscope. The new species is established based on provided morphological, zoogeographical and ecological investigations and data.

\section{TAXONOMICAL PART}

\section{Family NIPHARGIDAE}

\author{
MATERIAL EXAMINED: \\ NIPHARGUS DENARIUS, sp. n. Figs 1-8. \\ GREECE:G-2 (G-61) Cephalonia, loc. Efimia (Crini), 8.5.1977, 15 \\ exp. (leg. G. Pesce).
}

\section{DIAGNOSIS}

Body with relatively short and strong extremities, metasomal articles poorly setose along dorsoposterior margin; urosomal segments 1-2 with scarce number of setae and/or spines. Telson gaping, with dorsal, lateral and facial short spines. Coxae short, coxa 4 without lobe. Epimeral plate 3 almost subrounded, with convex posterior margin. Pleopods 1-3 with 2 retinacula, peduncle of pleopod 3 with 3-4 lateral plumose setae. Maxilla 1 outer plate with 7 spines (6 spines with one lateral tooth); maxilliped well developed. Gnathopods 1 and 2 of poorly unequal size, with propodus not larger than corresponding coxa, slightly trapezoid, with one S-, one R- and 3 L-spines, and 4-5 facial M-setae. Pereopods 
3-7 are strong, with additional number of strong spines along inner margin (sometimes dactylus of some pereopod 5 or pereopod 6 is with one spine only); basipodit of pereopods 5-7 without distinct lobe. Uropod 1 peduncle without ventrodistal tubercle in males; inner ramus much longer than outer ramus in males. Uropod 3 elongated in males, with long distal article of outer ramus; in female uropod 3 is shorter, with second article of outer ramus much shorter than first one. Sexual dimorphic characters present (epimeral plates, uropod 1, uropod $3)$.

\section{DESCRIPTION:}

MALE $15.0 \mathrm{~mm}$ (holotype). Body moderately slender, metasomal segments 1-3 along dorsoposterior margin with 5-6 short setae (fig. 3E). Urosomal segment 1 on each dorsolateral side with one seta; urosomal segment 2 on each dorsolateral side with one spine and one seta, or with 2 spine-like setae and one seta; urosomal segment 3 naked. Urosomal segment 1 on each ventroposterior side with one spine near basis of uropod 1 peduncle (fig. $5 \mathrm{H}$ ).

Epimeral plates 1-2 almost subrounded, with marked ventroposterior spine-like seta, along posterior convex margin appear a row of short setae. Epimeral plate 3 almost subrounded, with convex ventral and posterior margin, ventroposterior corner with spine-like setae and a row of numerous short setae along posterior convex margin (fig. 3E). Epimeral plate 2 with 2-3 subventral spines; epimeral plate 3 with $4-5$ subventral spines (fig. $3 \mathrm{E}$ ).

Head with short rostrum and subrounded lateral cephalic lobes, ventroanterior excavation well developed (fig. 1B), eyes absent.

Antenna 1 slightly exceeding half of body-length (ratio: 60:150). Peduncular articles 1-3 progressively shorter (ratio: 59:43:21), scarcely setose (fig. 1A); main flagellum slender, consisting of 23-24 articles (most of them with one short aesthetasc). Accessory flagellum 2-articulate, short (fig. 1A).

Antenna 2 moderately setose; peduncular article 3 with distoventral bunch of setae; peduncular article 4 poorly longer than article 5 (ratio: 54:51), both articles along ventral margin with 4 bunches of setae (the longest setae reaching or slightly exceeding the diameter of articles themselves). Flagellum slender, longer than last peduncular article (ratio: 70:51), consisting of 9 articles bearing setae as long as or longer than articles themselves (fig. 1C). Antennal gland cone short (fig. 1C).

MOUTHPARTS: Labrum much broader than long, with slightly convex distal margin (fig. 5A). Labium much broader than long, with entire subrounded outer lobes and small but well developed inner lobes (fig. 5B).

Mandible well developed, molar triturative. Right mandible: incisor with 4 teeth, lacinia mobilis bifurcate, with several teeth and 6 rakers. Left mandible: incisor with 5 teeth, lacinia mobilis with 4 teeth and 6 rakers. Palpus 3 -articulate: article 1 naked; article 2 with 10-11 strong setae (fig. 1D); article 3 subfalciform, longer than article 2 (ratio: 70:57), with nearly 27 D-setae and 5-6 E-setae; on outer face appear one group of $7 \mathrm{~A}$-setae, on inner face appear $8 \mathrm{~B}$-setae sitting in 3 groups (fig. 1E). 


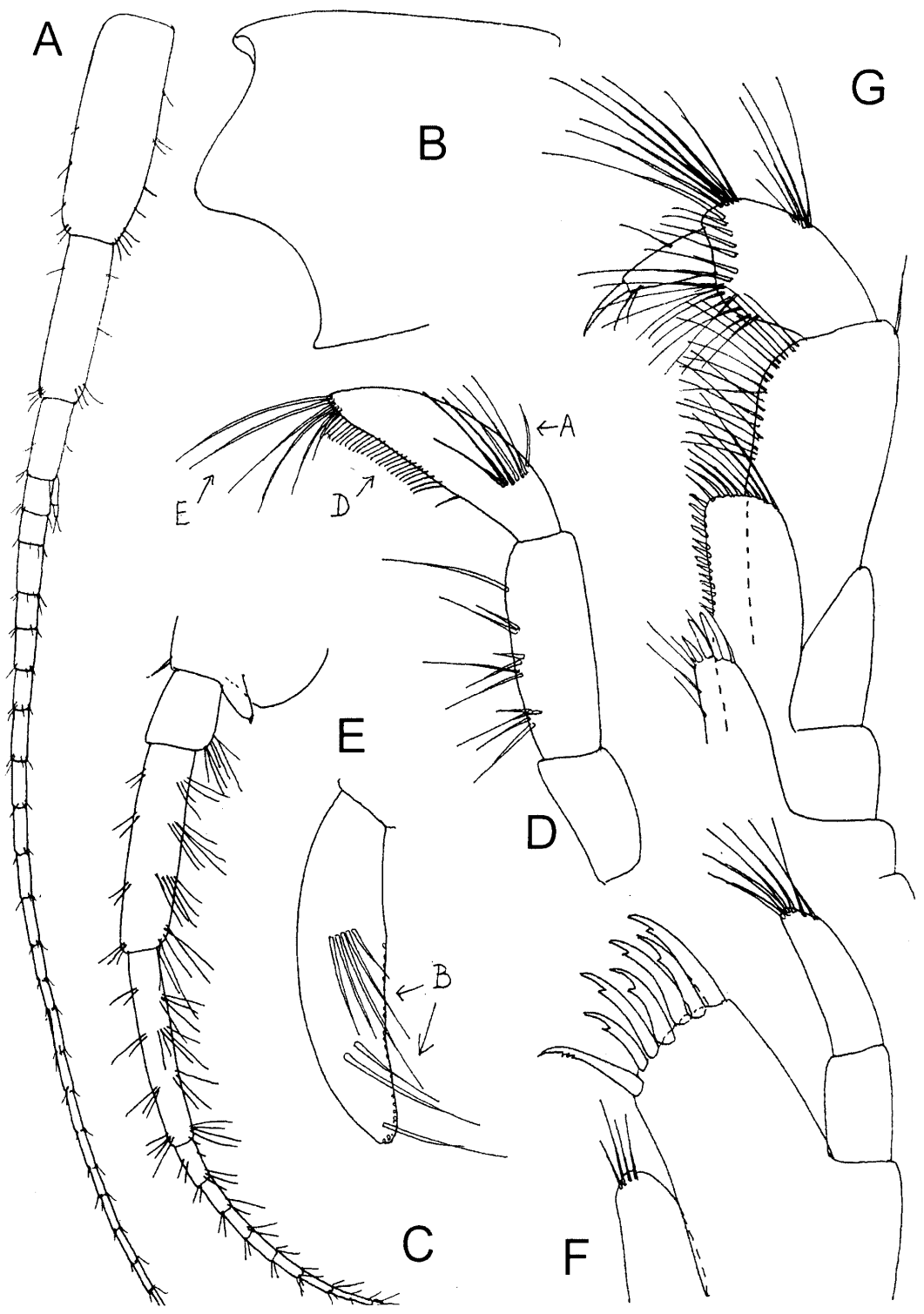

Fig. 1. Niphargus denarius, sp. n., Efimia, Cephalonia, male $15.0 \mathrm{~mm}$ (holotype): $\mathrm{A}=$ antenna $1 ; \mathrm{B}=$ head; $\mathrm{C}=$ antenna 2; $\mathrm{D}=$ mandibular palpus, outer face $[\mathrm{A}=$ facial $\mathrm{A}$-setae; $\mathrm{D}=$ lateral $\mathrm{D}$-setae; $\mathrm{E}=\operatorname{distal} \mathrm{E}$-setae]; $\mathrm{E}=$ distal palpus article of mandible, inner face $[\mathrm{B}=$ facial $\mathrm{B}$-setae $] ; \mathrm{F}=$ maxilla $1 ; \mathrm{G}=$ maxilliped 
Maxilla 1: inner plate with 3-4 simple setae (fig. 1F), outer plate with 7 spines (6 spines with one lateral tooth, one spine with 3 small lateral teeth); palpus 2articulate, not reaching tip of outer plate spines and provided with 6-8 distal setae.

Maxilla 2: both plates with numerous distal setae (fig. 5C).

Maxilliped: inner plate short, not reaching outer tip of palpus article 1 and bearing 3-4 pointed distal spines accompanied by several setae (fig. 1G). Outer plate not exceeding half of palpus article 2, with numerous spines along distolateral (mesial) margin. Palpus 4-articulate, article 2 along mesial margin with numerous simple setae; article 3 along outer margin with one medial and one distal bunch of setae; article 4 at inner margin with 2 setae near basis of the nail, along outer margin appear one medial seta (fig. 1G).

Coxae are relatively short, not covering to each other. Coxa 1 is broader than long (ratio: 63:48), with broadly subrounded ventroanterior corner; along margins of coxa 1 appear a row of nearly 15 short setae (fig. 2A). Coxa 2 slightly broader than long (ratio: 64:57), along ventral convex margin appear a row of nearly 20 short setae (fig. 2D).

Coxa 3 slightly broader than long (ratio: 73:67), along ventral convex margin with a row of nearly 18 short setae (fig. 3A). Coxa 4 broader than long (ratio: 72:60), along ventral slightly convex margin are attached nearly 17 short setae, ventroposterior lobe absent (fig. 3C).

Coxa 5 broader than long (ratio: 72:52), bilobed, anterior lobe nearly as long as coxa 4, posterior lobe with several short marginal setae (fig. 4A). Segment above coxa at ventroposterior corner is provided with 2-3 marginal setae (fig. 4A).

Coxa 6 smaller than coxa 5 but bilobed also, broader than long (ratio: 60:42), posterior lobe with several short marginal setae (fig. 4C). Segment above coxa at ventroposterior corner is provided with 5-6 short marginal setae (fig. 4C).

Coxa 7 entire, broader than long (ratio: 54:27), with convex ventral margin and 2-3 setae along posterior margin (fig. 4E). Segment above coxa at ventroposterior corner is provided with 5-6 short marginal setae (fig. 4E).

Gnathopods 1 and 2 are relatively small, with propodus nearly as large as corresponding coxa (fig. 2A, D). Gnathopod 1: article 2 along anterior and posterior margin with numerous long setae (fig. 2A); article 3 at posterior margin with one medial group of setae; article 4 with marked posterior bump; article 5 only slightly shorter than propodus (ratio: 42:52), at distoanterior tip with 1-2 groups of setae. Propodus trapezoid, slightly longer than broad (ratio: 97:83), along posterior margin with 6 transverse rows of setae (fig. 2B); palm poorly convex, inclined almost half of propodus-length, defined on outer face by one corner S-spine accompanied laterally by 3 serrate L-spines and 5 long facial Msetae (fig. 2C), on inner face by one subcorner R-spine (fig. 2C). Dactylus reaching remarkably posterior margin of propodus, along outer margin appear a row of 7 single or paired setae, along inner margin appear a row of several short setae (fig. 2B). 


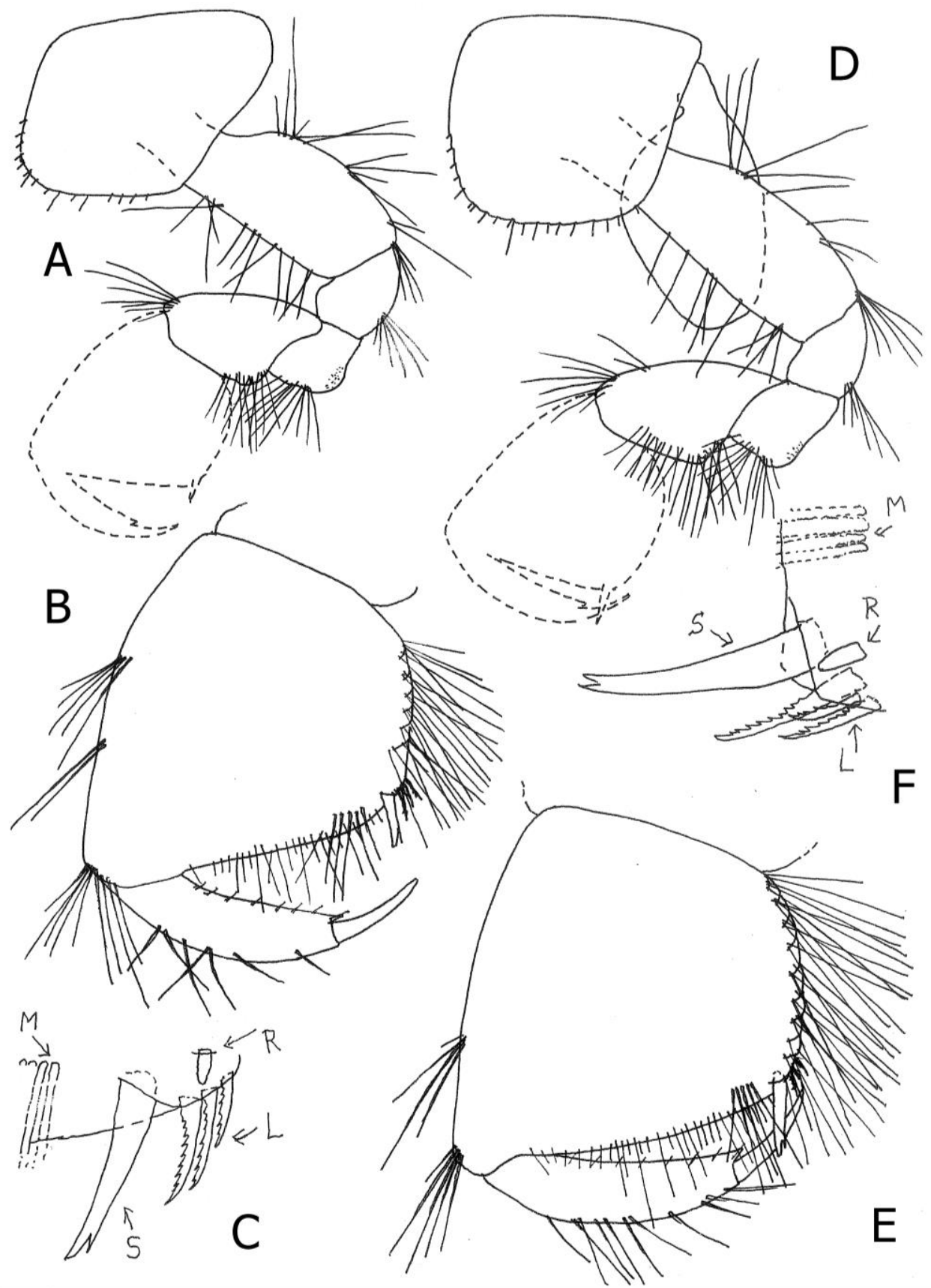

Fig. 2. Niphargus denarius, sp. n., Efimia, Cephalonia, male $15.0 \mathrm{~mm}$ (holotype): A$\mathrm{B}=$ gnathopod 1 , outer face; $\mathrm{C}=$ distal corner of gnathopod 1 propodus, inner face $[\mathrm{S}=$ corner S-spine; $\mathrm{L}=$ lateral serrate spines; $\mathrm{M}=$ facial $\mathrm{M}$-setae; $\mathrm{R}=$ subcorner $\mathrm{R}$-spine]; $\mathrm{D}-\mathrm{E}=$ gnathopod 2 , outer face; $\mathrm{F}=$ distal corner of gnathopod 2 propodus, inner face $[\mathrm{S}=$ corner $\mathrm{S}$-spine; $\mathrm{L}=$ lateral serrate spines; $\mathrm{M}=$ facial $\mathrm{M}$-setae; $\mathrm{R}=$ subcorner $\mathrm{R}$ spine]. 
Gnathopod 2 is poorly larger than gnathopod 1; article 2 along anterior and posterior margin with row of long simple setae (fig. 2D); article 3 at posterior margin with one bunch of setae; article 4 along posterior margin with marked bump (fig. 2D); article 5 slightly shorter than propodus (ratio: 50:55), along anterior margin with 2 groups of setae. Propodus trapezoid, slightly longer than broad (ratio: 111:90), along posterior margin with 9 transverse rows of setae (fig. 2E); palm slightly convex, inclined slightly less than half of propodus-length, defined on outer face by one corner S-spine accompanied laterally by 3 slender L-spines and 5 facial long M-setae (fig. 2F), on inner face by one subcorner Rspine (fig. 2F). Dactylus remarkably reaching posterior margin of propodus, along outer margin provided with a row of 11 single or paired setae, along inner margin with a row of short setae.

Pereopods 3 and 4 rather similar to each other, moderately stout. Pereopod 3: article 2 along anterior margin with several long proximal setae and a row of mediodistal short setae, along posterior margin with several bunches of long setae. Articles 4-6 of unequal length (ratio: 65:45:50); article 4 along posterior margin with 4 bunches of setae (the longest setae reaching or hardly exceeding diameter of article itself); article 5 along posterior margin with 3 bunches of setae (the longest setae much exceeding diameter of article itself); article 6 along posterior margin with 5 single or paired short spines accompanied by $0-1$ short seta (fig. 3A). Dactylus much shorter than article 6 (ratio: 20:50), short and strong, along inner margin with 3 strong spines, along outer margin with one medial plumose seta (fig. 3B); nail strong, shorter than pedestal (ratio: 29:35).

Pereopod 4: article 2 along anterior margin with 5-6 long proximal setae and a row of nearly 10 short mediodistal setae (fig. 3C); articles 4-6 of unequal length (ratio: 63:44:50): article 4 along posterior margin with 5 bunches of setae (the longest setae are nearly as long as diameter of article itself); article 5 along posterior margin with 3 bunches of spines and short setae; article 6 along posterior margin with row of 5 single or paired short spines accompanied by single short setae. Dactylus strong, much shorter than article 6 (ratio: 16:50), along inner margin with 3 strong spines, along outer margin with one medial plumose seta (fig. 3D); nail is nearly as long as pedestal.

Pereopods 5-7 relatively stout. Pereopod 5 is slightly shorter than pereopods 6 and 7, with article 2 longer than broad (ratio: 70:47), along anterior margin with 7 groups of short spines and/or setae; along posterior margin with nearly 20 short setae, ventroposterior lobe not fully developed (fig. 4A); articles 4-6 of unequal length (ratio: 45:48:50), along anterior margin mainly with bunches of short setae, along posterior margin with bunches of short spines sometimes accompanied by single short seta. Article 2 is longer than article 6 (ratio: 70:50). Dactylus is much shorter than article 6 (ratio: 17:50), along inner margin with 2 strong spines, along outer margin with one median seta (fig. 4B); nail slightly shorter than pedestal (ratio: 26:31).

Pereopod 6: article 2 remarkably longer than broad (ratio: 76:49), along anterior margin with 7 groups of short spine-like setae or setae, along posterior poorly medially concave margin with nearly 22 short setae, ventroposterior lobe 
not fully developed (fig. 4C); articles 4-6 of unequal length (ratio: 55:60:71), along both margins with groups of short spines and setae. Article 6 is only slightly shorter than article 2 (ratio: 71:76). Dactylus is short and strong, much shorter than article 6 (ratio: 18:71), along inner margin with 3 strong spines, along outer margin with one median seta (fig. 4D); nail is shorter than pedestal (ratio: 33:50).

Pereopod 7: article 2 much longer than broad (ratio: 86:51), along anterior margin with 7 single or paired spine-like setae, along posterior poorly convex margin with nearly 23 short setae, ventroposterior lobe not fully developed (fig. 4E). Articles 4-6 of unequal length (ratio: 48:61:75), along margins with groups of short spines and short setae not reaching diameter of articles themselves. Article 2 is slightly longer than article 6 (ratio: 86:75). Dactylus is much shorter than article 6 (ratio: 23:75), strong, along inner margin with 4 strong spines, along outer margin with one medial seta (fig. 4F); nail is shorter than pedestal (ratio: 34:55).

Pleopods 1-3 with 2 retinacula each. Peduncle of pleopod 1 with 4-5 setae at distoanterior part (fig. 5D); peduncle of pleopod 2 with 2 distal setae at anterior margin and one medial short seta at posterior margin (fig. 5E). Peduncle of pleopod 3 along posterior margin with 3 strong setae, along outer margin with 4 plumose and one simple seta (fig. 5F).

Uropod 1 is long, peduncle with dorsoexternal row of spines and with dorsointernal row of setae (fig. 5H), ventrodistal tubercle absent. Inner ramus nearly as long as peduncle, with several lateral and distal short spines, as well as with 5 bunches of simple setae along ventral margin. Outer ramus reaching nearly half of inner ramus-length, with several lateral and distal short spines (spines never reaching diameter of article itself) (fig. $5 \mathrm{H}$ ).

Uropod 2: peduncle with single lateral and distal spines; inner ramus bearing several lateral and distal short spines (fig. 5G) and 3 simple short setae at outer margin; outer ramus hardly shorter than inner one, with several lateral and distal short spines.

Uropod 3 long: peduncle much longer than broad (ratio: 49:25), with single distal spines; inner ramus slightly shorter than peduncle (ratio: 36:49), with 3 lateral and one distal spine accompanied by distal bunch of short setae (fig. 5 I); outer ramus 2-articulated, narrow; first article along both margins and tip with bunches of single or paired very short spines and simple setae; second article exceeding half of first article-length (ratio: 97:135), along both margins and tip with bunches of short simple setae.

Telson slightly broader than long (ratio: 92:80), gaping, incised nearly $2 / 3$ of telson-length; each lobe with 3 short distal spines, along outer margin with one spine, along inner (mesial) margin with 2 single spines or one spine and 2 setae; a pair of facial spines and 0-1 seta appear on each lobe (fig. 3F).

Coxal gills 1-4 ovoid, moderately large, not exceeding ventral tip of corresponding article 2 (figs. 2D; 3A, C); coxal gills 5 and 6 much smaller, ovoid (fig. 4A, C). 


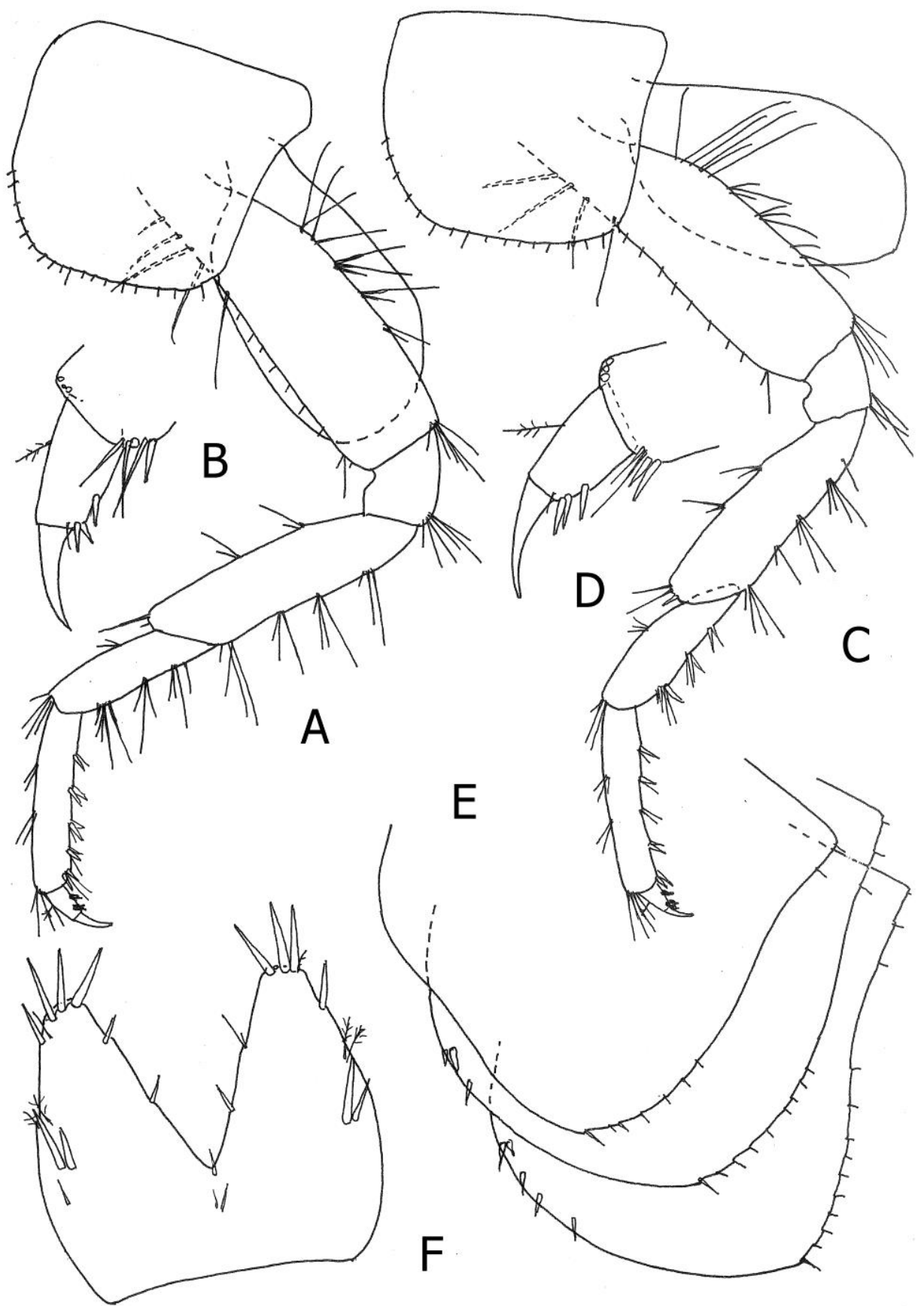

Fig. 3. Niphargus denarius, sp. n., Efimia, Cephalonia, male $15.0 \mathrm{~mm}$ (holotype): $\mathrm{A}=$ pereopod $3 ; \mathrm{B}=$ dactylus of pereopod $3 ; \mathrm{C}=$ pereopod $4 ; \mathrm{D}=$ dactylus of pereopod $4 ; \mathrm{E}=$ epimeral plates $1-3 ; \mathrm{F}=$ telson. 


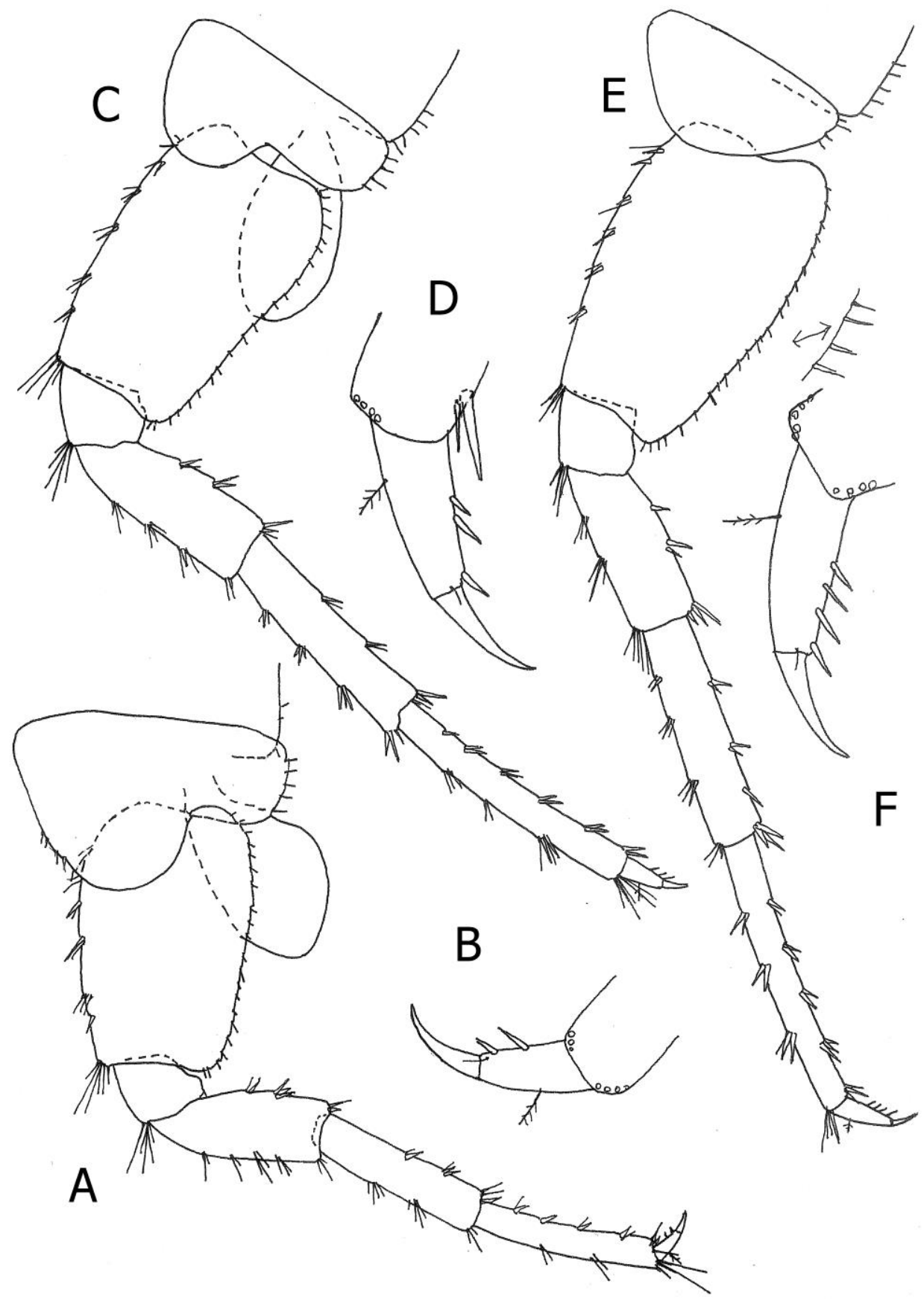

Fig. 4. Niphargus denarius, sp. n., Efimia, Cephalonia, male $15.0 \mathrm{~mm}$ (holotype): $\mathrm{A}=$ pereopod $5 ; \mathrm{B}=$ dactylus of pereopod $5 ; \mathrm{C}=$ pereopod $6 ; \mathrm{D}=$ dactylus of pereopod $6 ; \mathrm{E}=$ pereopod $7 ; \mathrm{F}=$ dactylus of pereopod 7 . 
FEMALE $9.5 \mathrm{~mm}$ with setose oostegites (paratype). Body moderately slender, metasomal segments 1-3 at dorsoposterior margin with 5 short setae (fig. $5 \mathrm{~J})$; urosomal segment 1 on each dorsolateral side with one seta; urosomal segment 2 on each dorsolateral side with one spine and one seta, or 2 spines and one seta; urosomal segment 3 naked. Urosomal segment 1 on each ventroposterior corner with one spine near basis of uropod 1 peduncle (fig. 8A).

Epimeral plate 1 with marked ventroposterior corner, posterior convex margin bearing a row of short setae, ventral margin slightly concave in the middle (fig. 5J). Epimeral plate 2 almost subrounded, with well-marked ventroposterior corner spine-like seta and convex posterior margin bearing a row of short setae, ventral margin is convex. Epimeral plate 3 is poorly angular, with marked ventroposterior corner and corner spine-like seta, ventral margin is strongly convex, posterior margin slightly convex, with a row of short setae (some setae are spine-like setae) (fig. 5J). Epimeral plates 2 and 3 are with 2 subventral spines each.

Head like that in male. Antenna 1 almost reaching half of body-length (ratio: 45:95); main flagellum consisting of 20 articles. Accessory flagellum 2articulated, slightly exceeding half of last peduncular article.

Antenna 2 peduncular articles 4 and 5 with 4-5 bunches of ventral setae; flagellum consisting of 9 articles. Antennal gland cone is short.

Mouthparts mainly like these in male. Mandibular palpus article 1 naked, article 2 with 7-9 setae; palpus article 3 with nearly 23-24D-, 5-6E-, 6A- and 4-5 B setae.

Inner plate of maxilla 1 with 3 setae, outer plate with 7 spines (6 spines with one lateral tooth, one spine with 2-3 small lateral teeth), palpus provided with 6-setae.

Maxilliped: inner plate with 3 spines, palpus article 3 at outer margin with 2 bunches of setae; article 4 at inner margin with 2 setae near basis of the nail.

Coxae 1-4 are rather longer than these in male. Coxa 1 is rhomboid, slightly longer than broad (ratio: 50:45), with broadly subrounded ventroanterior corner, and bearing nearly 21 short marginal setae (fig. 6A). Coxa 2 is longer than broad (ratio: 60:47), along ventral convex margin with nearly 17 short unequal setae (fig. 6C). Coxa 3 only poorly longer than broad (ratio: 60:57), along ventral margin with 15 short setae (fig. $6 \mathrm{E}$ ). Coxa 4 is slightly longer than broad (ratio: 62:54), along ventral margin with nearly 18 short unequal setae, ventroposterior lobe is not developed (fig. 6F).

Coxa 5 is much broader than long (ratio: 72:50), anterior lobe almost as long as coxa 4, broadly subrounded, posterior lobe with 5-6 short posterior marginal setae (fig. 7A). Segment above coxa at ventroposterior corner is provided with 2-3 marginal setae (fig. 7A).

Coxa 6 is smaller than coxa 5, bilobed, broader than long (ratio: 60:42), posterior lobe along posterior margin with nearly 5 short setae (fig. 7C). Segment above coxa at ventroposterior corner is provided with 5-6 short marginal setae (fig. 7C). 


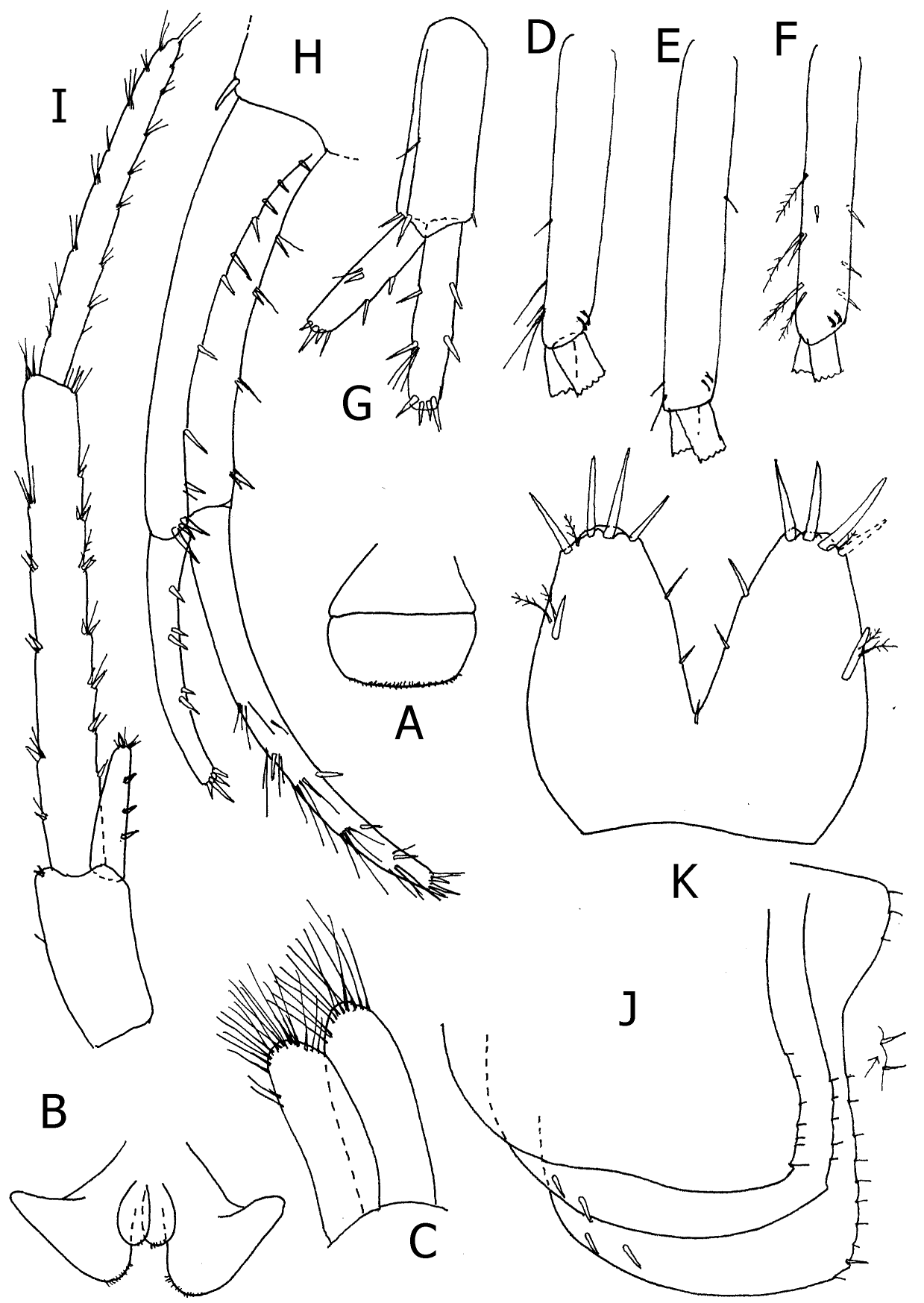

Fig. 5. Niphargus denarius, sp. n., Efimia, Cephalonia, male $15.0 \mathrm{~mm}$ (holotype): $\mathrm{A}=$ labrum; $\mathrm{B}=$ labium; $\mathrm{C}=$ maxilla $2 ; \mathrm{D}=$ peduncle of pleopod $1 ; \mathrm{E}=$ peduncle of pleopod $2 ; \mathrm{F}=$ peduncle of pleopod $3 ; \mathrm{G}=\operatorname{uropod} 2 ; \mathrm{F}=\operatorname{uropod} 1 ; \mathrm{I}=\operatorname{uropod} 3$. Female $9.5 \mathrm{~mm}$ (paratype): $\mathrm{J}=$ epimeral plates $1-3 ; \mathrm{K}=$ telson. 

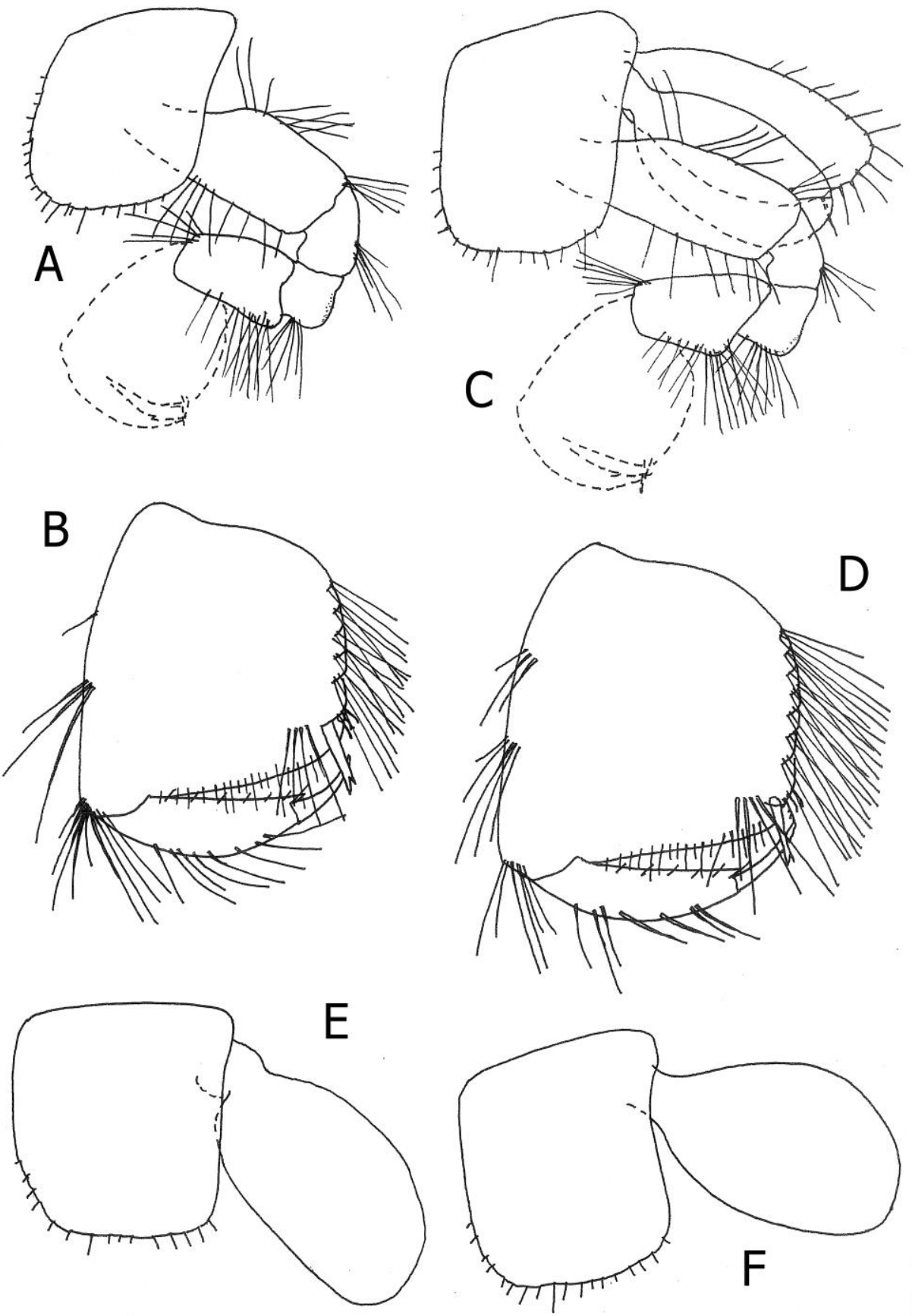

Fig. 6. Niphargus denarius, sp. n., Efimia, Cephalonia, female $9.5 \mathrm{~mm}$ (paratype): $\mathrm{A}-\mathrm{B}=$ gnathopod 1 , outer face; $\mathrm{C}-\mathrm{D}=$ gnathopod 2 , outer face; $\mathrm{E}=$ coxa $3 ; \mathrm{F}=$ coxa 4. 
Coxa 7 is much broader than long (ratio: 55:27), entire, with convex ventral margin and 2-3 setae at posterior margin (fig. 7D). Segment above coxa at ventroposterior margin is provided with 3-4 short setae (fig. 7D).

Gnathopods 1 and 2 are relatively small, poorly unequal in size and with propodus poorly smaller than corresponding coxa (fig. 6A, C). Gnathopod 1: article 2 stout, along anterior and posterior margin with numerous long simple setae (fig. 6A). Article 3 at posterior margin with one bunch of setae; article 4 with visible posterior bump; article 5 shorter than propodus (ratio: 28:42), along anterior margin with one distal bunch of setae. Propodus almost quadrate, longer than broad (ratio: 82:69), along posterior margin with 5 transverse rows of setae (fig. 6B). Palm inclined nearly $1 / 3$ of propodus length, poorly convex, defined on outer face by one S-spine accompanied laterally by 3 slender L-spines and 4 long facial M-setae, on inner face by one subcorner R-spine. Dactylus reaching posterior margin of propodus, along outer margin with row of 8 single or paired medial setae, along inner margin with several short setae (fig. 6B).

Gnathopod 2 is only poorly larger than gnathopod 1; article 2 along both margins with long setae; article 3 at posterior margin with one bunch of median setae (fig. 6C); article 4 with marked posterior bump; article 5 along anterior margin with one distal bunch of setae. Propodus almost quadrate, slightly longer than broad (ratio: 85:78), along posterior margin with 7 transverse rows of setae (fig. 6D), palm slightly convex, inclined nearly $1 / 3$ of propodus-length, defined on outer face by one corner S-spine accompanied laterally by $3 \mathrm{~L}$-spines and 5 long facial M-setae, on inner face by one subcorner R-spine. Dactylus reaching posterior margin of propodus, along outer margin with 7 medial setae, along inner margin with several short setae.

Pereopods 3 and 4 like these in male, with dactylus bearing 2 strong spines along inner margin and one median plumose seta at outer margin.

Pereopods 5-7 rather stout and short. Pereopod 5: article 2 longer than broad (ratio: 74:50), along anterior margin with 5 groups of spine-like setae, along posterior convex margin with 12 short setae, ventroposterior lobe not fully developed (fig. 7A). Articles 4-6 of unequal length (ratio: 46:48:55), articles along both margins with short spines and setae. Article 2 is longer than article 6 (74:55). Dactylus is much shorter than article 6 (ratio: 18:55), strong, along inner margin with one spine, along outer margin with one medial plumose seta (fig. 7B); nail is shorter than pedestal (ratio: 31:38).

Pereopod 6: article 2 distinctly longer than broad (ratio: 85:55), along anterior margin with 6 groups of spine-like setae, along posterior poorly convex margin with nearly 15 short setae, ventroposterior lobe not fully developed (fig. 7C). Articles 4-6 of unequal length (ratio: 54:63:77), along both margins with bunches of short spines and short setae. Article 2 is slightly longer than article 6 (ratio: 85:77). Dactylus is much shorter than article 6 (ratio: 23:77), strong, along inner margin with 1-2 spines, along outer margin with one medial seta; nail is shorter than pedestal (ratio: 25:40). 


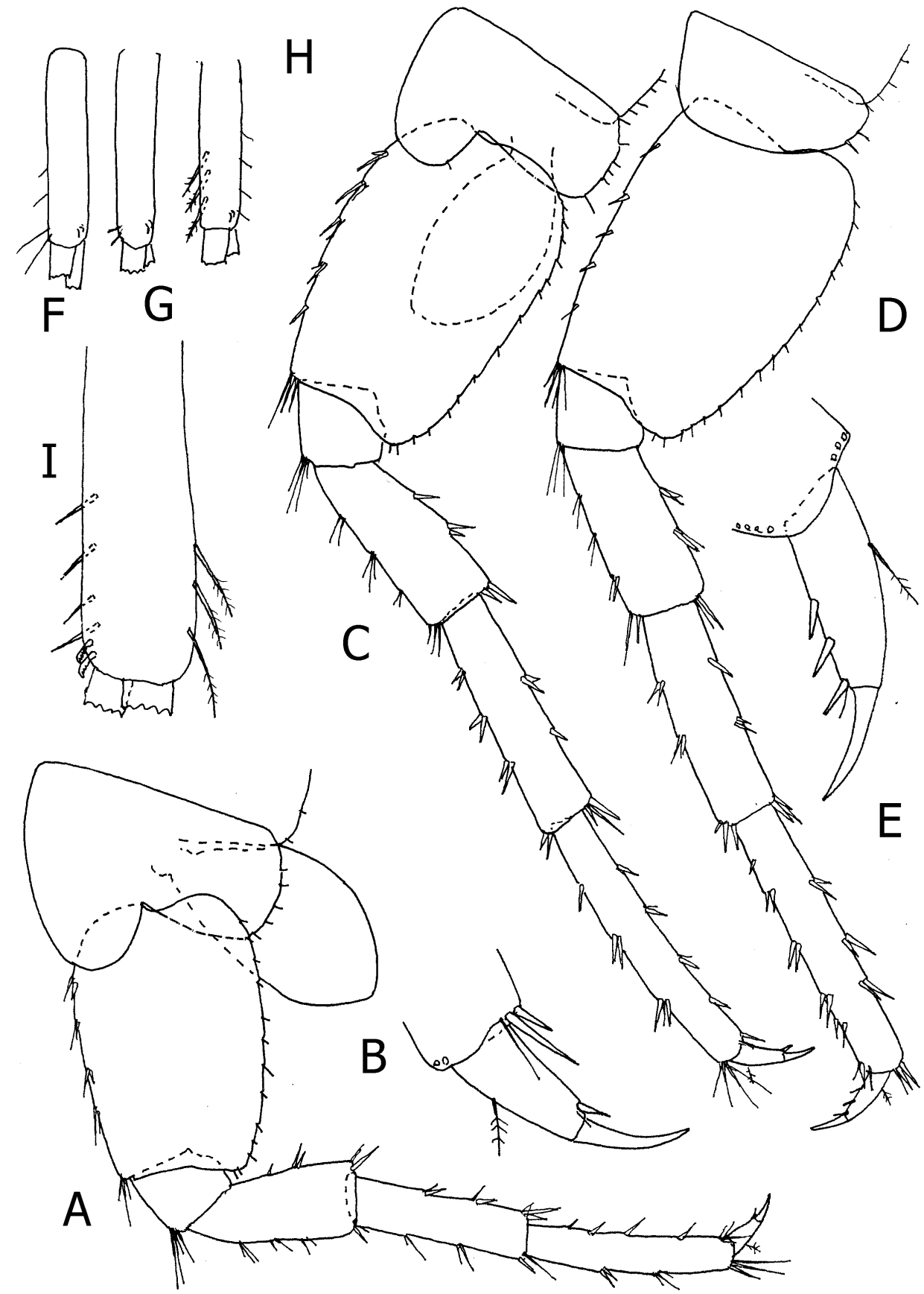

Fig. 7. Niphargus denarius, sp. n., Efimia, Cephalonia, female $9.5 \mathrm{~mm}$ (paratype): $\mathrm{A}=$ pereopod $5 ; \mathrm{B}=$ dactylus of pereopod $5 ; \mathrm{C}=$ pereopod $6 ; \mathrm{D}=$ pereopod 7; $\mathrm{E}=$ dactylus of pereopod $7 ; \mathrm{F}=$ pleopod 1 peduncle; $\mathrm{G}=$ pleopod 2 peduncle; $\mathrm{H}-\mathrm{I}=$ pleopod 3 peduncle. 


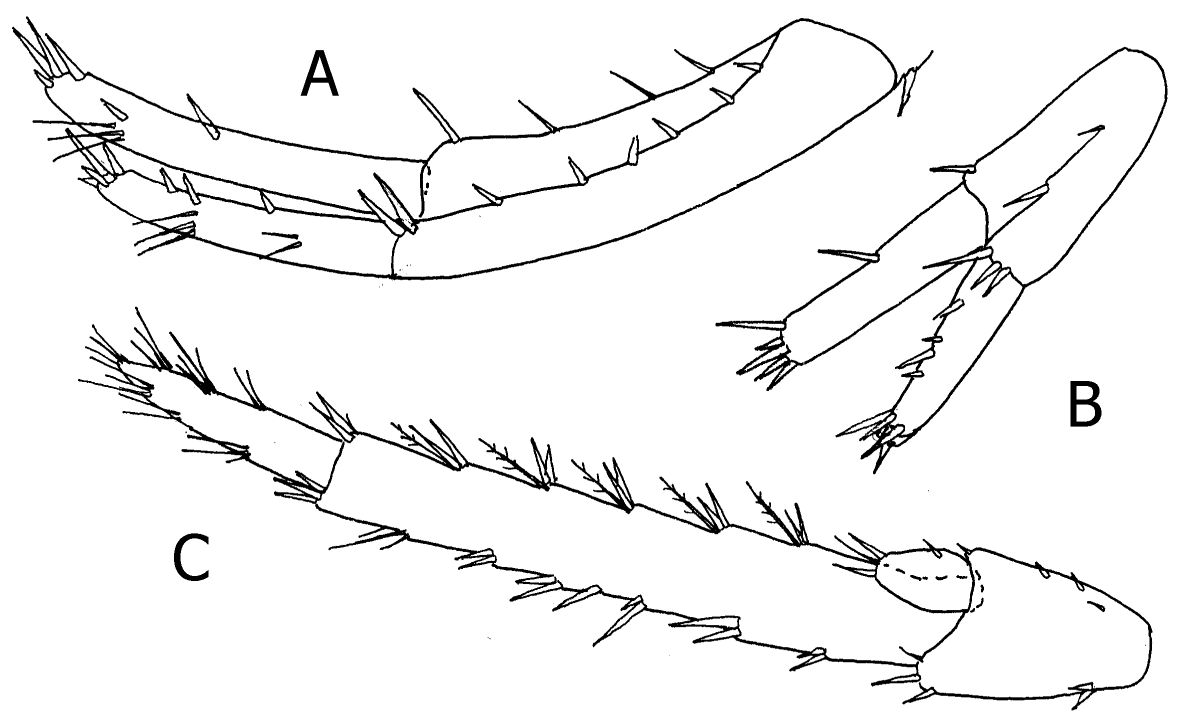

Fig. 8. Niphargus denarius, sp. n., Efimia, Cephalonia, female $9.5 \mathrm{~mm}$ (paratype): $\mathrm{A}=\operatorname{uropod} 1 ; \mathrm{B}=\operatorname{uropod} 2 ; \mathrm{C}=\operatorname{uropod} 3$.

Pereopod 7: article 2 is longer than broad (ratio:88:59), along anterior margin with 6 spine-like setae and one bunch of distal setae, along posterior slightly convex margin with 17 short setae, ventroposterior lobe not fully developed (fig. 7D). Articles 4-6 of unequal length (ratio: 50:60:78), articles along both margins with bunches of short spines and setae. Article 2 is slightly longer than article 6 (ratio: 88:78). Dactylus is shorter than article 6 (ratio: 27:78), along inner margin with 3 strong spines, along outer margin with one medial seta (fig. 7E); nail is much shorter than pedestal (ratio: 32:61).

Pleopods 1-3 with 2 retinacula each. Peduncle of pleopod 1 with 4 anterior marginal setae (fig. 7F); peduncle of pleopod 2 with 2 distoanterior setae (fig. $7 \mathrm{G}$ ); peduncle of pleopod 3 at posterior margin with 4 spine-like setae, along outer margin with 3 plumose setae (fig. $7 \mathrm{H}, \mathrm{I}$ ).

Uropod 1: peduncle with dorsoexternal row of spines and with dorsointernal row of setae (except distal spine) (fig. 8A). Inner ramus is shorter than peduncle, bearing only 1-2 lateral spines and 3 simple setae, as well as 5 distal short spines. Outer ramus reaching nearly $3 / 4$ of inner ramus-length, bearing several lateral short $\mathrm{sp}$ ines and 3 bunches of short simple setae; ramus ended with 4-5 short spines.

Uropod 2: peduncle with single lateral and distal spines (fig. 8B); inner ramus provided with one lateral and 5 distal spines; outer ramus is almost as long as inner ramus, with 4 lateral and 5 distal short spines.

Uropod 3 is relatively short: peduncle only slightly longer than broad (ratio: 45:30), bearing single lateral and distal spines; inner ramus short, scalelike, with one lateral and 2 distal spines accompanied by one smooth seta (fig. 
$8 \mathrm{C})$. Outer ramus is 2-articulated; first article broad, along outer margin with 8 groups of strong short spines, along inner margin with 6 bunches of spines accompanied by single short plumose setae; second article narrower and shorter than first one (ratio: 48:128), bearing 3 bunches of simple setae along both margins and tip.

Telson gaping, slightly broader than long (ratio: 90:80), incised nearly $3 / 5$ of telson-length (fig. 5K); each lobe is provided with 4 distal short spines, as well as with 2 setae or spines along mesial margin; one spine appears on the face of each lobe; a pair of short plumose setae is implanted near the middle of each lobe.

Coxal gills ovoid, moderately long (figs. 6C, F; 7A, C), never exceeding ventral tip of corresponding basipodit.

Oostegites large, with long marginal setae (fig. 6C).

\section{VARIABILITY.}

Epimeral plates in females are, in general, slightly more angular than these in males. Scarce number of dorsoposterior short setae on metasomal segments 13 (4-6 setae) is present in males and females.

Epimeral plate 2 in males is with 2-3 subventral spines, epimeral plate 3 with 3-5 subventral spines. Maxilla 1 inner plate is with 3-4 setae; maxilliped inner plate with 3-4 distal pointed spines. Basipodit of pereopods 5-7 along posterior margin is with short setae in males and females; often some of these setae are stronger, spine-like setae (fig. 4E), ventroposterior lobe never fully developed.

Dactylus of pereopods 3-7 in males and females is provided with 2-3 spines, occasionally dactylus of pereopods 5 or pereopod 6 is with only one spine at inner margin.

Plumose setae on peduncle of pleopod 3 in males and females are always present. Uropod 2 in males and females is with almost subequal rami or with inner ramus scarcely longer than outer one.

HOLOTYPE: male $15.0 \mathrm{~mm}$; paratype: female $9.5 \mathrm{~mm}$ with setose oostegites. Holotype and paratypes are deposited in the Karaman`s Collection in Podgorica, Montenegro.

DISTRIBUTION: Known from type-locality only.

\section{REMARKS AND AFFINITIES.}

The new species, Niphargus denarius, sp. $\mathrm{n}$. is characterized by presence of additional number of spines on pereopods 3-7, the character observed in various taxa from Europe and Near East, but not mentioned among known taxa from Greece.

$N$. denarius is rather similar to the species Niphargus rotundus G. Karaman, 2016c known from well in Montelupo Albeze, $450 \mathrm{~m}$ a.s.l. (Cuneo, Italy) (epimeral plates, short strong pereopods with strong dactyls bearing 
additional spines, gaping telson, elongated uropods 1 and 3 in males, etc.), but $N$. denarius differs from it by lower number of $\mathrm{M}$-setae on propodus of gnathopods, by presence of plumose setae on peduncle of pleopod 3 etc.

Another species with the presence of additional spines on dactylus of pereopods 3-7 is $N$. stankoi G. Karaman 1974, known from spring near village Bukovo on road Resen-Ohrid, Macedonia. This species differs from $N$. denarius by different shape of propodus of gnathopods, different epimeral plates, by subequal rami of uropod 1 in males, strongly spinose telson etc.

In western Dinaric region (Croatia, Bosnia and Herzegovina, Montenegro ) are present several taxa of the Niphargus illidzensis-complex with elevated number of spines on dactylus, but they differ from our species by various other taxonomical characters, including more acute epimeral plates, pleopods, etc. (S. Karaman, 1950).

In Italy are known several other species with additional number of spines on dactylus of pereopods 3-7 [N. sestoputeanus G. Karaman, 2016c (loc. typ.: Sesta Godano, Passo del Rastrello, $1000 \mathrm{~m}$ a.s.l., N. of La Spezia, Italy); N. elegans Garbini 1894 (loc. typ.: S. Pancrazio near Verona, Italy), etc.] but $N$. denarius differs from all of them by combination of different taxonomical characters.

In Bulgaria is present endemic species Niphargus bulgaricus Andreev 2001 [loc. typ.: Lake Bolata (Shabla, N. of cap Caliakra, Varna reg.] with elevated number of spines on dactylus of pereopods, but this species is characterized by acute epimeral plates.

In the subterranean waters of France are present various Niphargus taxa with elevated number of spines on dactylus of pereopods ( $N$. ladmiraulti Chevreux 1901, N. ciliatus Chevreux 1906, N. balazuci Schellenberg 1951, etc.), but these species differ from our species by various characters.

DERIVATIO NOMINIS. The name "denarius" should allude to the shape of old Roman money "denarius", according to the subrounded epimeral plates of this species.

\section{CONCLUSION}

Fauna of Amphipoda in Greece is still only partially known, and nearly 15 taxa of genus Niphargus are known from this region. Niphargus denarius, sp. $\mathrm{n}$. described from Cephalonia is rather similar to the species Niphargus rotundus G. Karaman 2016 from Italy, and Niphargus puteanus-complex in general, but differs from later by several morphological characters. Elevated number of spines on dactylus of pereopods 3-7 is present in numerous taxa of genus Niphargus over Europe, including Balkan peninsula, but all of them differs from $N$. denarius by combination of taxonomical characters. Although the presence or absence of additional spines on dactylus of pereopods 5-7 is good morphological and taxonomical characters, we don`t know its real value for higher taxonomical categories. 


\section{ACKNOWLEDGEMENTS}

I am thankful to Prof. Dr. Giuseppe Pesce from the University of Aquilla for the collected material used in this study.

\section{REFERENCES}

Andreev, S. 2001. Niphargus bulgaricus sp. n. et deux especes nouvelles pour la faune de Bulgarie-Niphargopsis trispinosus Dancau et Gammarus roeseli (sic!) Gervais (Amphipoda: Niphargidae, Gammaridae).- Historia Naturalis Bulgarica 13: 7987.

Chevreux, E. 1901. Amphipodes des eaux souterraines de France et d’Algerie. I-VI. Bulletin de la Société zoologique de France: 168-222.

Chevreux, E. 1906. Niphargus ciliatus n. sp., in: Peyerimhoff, P.: Recherches sur la faune cavernicole des Basses-Alpes.- Annales de la Societe Entomologique de France, 75: 203-222.

Garbini, A. 1894. Gammarus ciechi in acque superficialis basse. - Academia d`Agricoltura Arti e Commercio di Verona, 70 (3): 107-112.

Karaman, G. 1969. XXVII. Beitrag zur Kenntnis der Amphipoden. Arten der Genera Echinogammarus Stebb. und Chaetogammarus Mart. an der jugoslawischer Adriaküste. Glasnik Republičkog zavoda zazaštitu prirode i Prirodnjačke zbirke u Titogradu. 2: 59-84.

Karaman, G. 1970. XXV. Beitrag zur Kenntnis der Amphipoden. Kritische Bemerkungen über Echinogammarus acarinatus (S. Kar., 1931) und Echinogammarus stocki n. sp. - Poljoprivreda i šumarstvo, Titograd, 16 (1-2): 45-66.

Karaman, G. 1974. XLVI. Contribution to the Knowledge of the Amphipoda. Two subterranean Niphargus species from Yugoslavia, N. stankoi, n. sp. and N. ilidzensis Schäferna (Fam. Gammaridae). - Glasnik Republičkog. zavoda za zaštitu prirode- Prirodnjačkog muzeja Titograd, 6: 35-57 (1973).

Karaman, G. 2012. Further investigations of the subterranean genus Niphargus Schiödte, 1849 (fam. Niphargidae) in Serbia. (Contribution to the Knowledge of the Amphipoda 264). - Agriculture and Forestry, Podgorica, 58 (2): 45-64.

Karaman, G. 2015. New data of genus Niphargus Schiödte, 1849 (Fam. Niphargidae) from Greece (Contribution to the knowledge of the Amphipoda 284).Agriculture \& Forestry, 61 (4): 43-60, Podgorica.

Karaman, G. 2016a. On two new or interesting species of the family Niphargidae from Greece and Croatia. (Contribution to the Knowledge of the Amphipoda 286).Ecologica Montenegrina 5: 1-17.

Karaman, G. 2016b. Two new genera of the family Niphargidae from Greece (Contribution to the Knowledge of the Amphipoda 287). - Agriculture \& Forestry, 62 (1): 7-27.

Karaman, G. 2016c. On two new Niphargus species (Fam. Niphargidae) from Italy (Contribution to the Knowledge of the Amphipoda 288).- Ecologica Montenegrina 5: 70-89.

Karaman, G. 2017. A new member of the genus Niphargus Schiödte, 1849 (Amphipoda Gammaridea, fam. Niphargidae) from Crete Island, Greece (Contribution to the Knowledge of the Amphipoda 293).- Ecologica Montenegrina, 10: 1-10, 4 figs.

Karaman, S. 1950. Niphargus ilidzensis Schaeferna i njegovi srodnici u Jugoslaviji. (= Supraniphargus ilidzensis Schäferna und seine Nächstverwandten in 
Jugoslavien).- Srpska Akademija Nauka, Posebna Izdanja knj. 158, Odelenje Prirodno-matematičkih nauka, Beograd, 2: 51-85, figs. 1-40.

Karaman, S. 1960. Weitere Beiträge zur Kenntnis der Jugoslavischen Niphargiden.Glasnik Prirodnjačkog muzeja Beograd, Ser. B, 15: 75-90, figs. 1-19.

Schäferna, K. 1922. Amphipoda balcanica, with notes about other freshwater Amphipoda. - Vestnik Královské. české Spolecnosti nauk, Trida matematičkoprirodovedecká, Praha, 1921-1922, 2: 1-111, 31 figs., 2 pls.

Schellenberg, A. 1951. Un Niphargus nouveau du Sud-est de la France. - Bulletin du Muséum National d'Histoire Naturelle, Paris, 2-e ser., 23 (2): 187-189. 